$\xi=\mathbf{\alpha}$

\title{
Some hemato-biochemical, bacteriological and pathological effects of Moringa oleifera leaf extract in broiler chickens
}

\author{
Hossam Allam ${ }^{1}$, Abdelazem M Abdelazem ${ }^{2 *}$, Halla Salah Farag ${ }^{3}$, Abdalla Hamed ${ }^{4}$ \\ Poultry ${ }^{1}$, Biochemistry ${ }^{3}$ and Pathology ${ }^{4}$ departments, Animal Health Research Institute, Zagazig Branch, Sharkia, Egypt \\ ${ }^{2}$ Vet. Teaching Hospital of Fac. of Vet. Med. Benha University, Egypt \\ *Corresponding author E-mail: abdelazem.abdelazem@fvtm.bu.edu.eg
}

\begin{abstract}
Cloacal swabs were collected from 300 broiler chicks (50 dead, 50 diseased and 200 healthy) for bacteriological examintion. Out of 300 examined cloacal swabs $26(52 \%)$ dead, $28(56 \%)$ diseased and $28(14 \%)$ from healthy chicks were positive for bacteria. Moringa oleifera leaf extract inhibits growth of E. coli and Salmonella spp. Post bacteriological examination 120 chicks free from bacterial infection, one day old were divided into 3 equal groups. 1st group healthy chicks (control), 2nd and 3rd groups chicks received $200 \mathrm{mg} / \mathrm{kgm}$ bwt watery and alcoholic moringa oleifera leaf extract daily for 30 successive days in drinking water respectively. Effect of moringa leaf extract on body weight, feed conversion rate and haemato-biochemical analysis beside pathological changes of some internal organ were study.

Moringa leaf extracts (watery \& alcoholic) induced significant increase in body weight gain, RBCs, Hb, PCV\% WBCs, total proteins, albumin, globulins, SOD beside significant decrease in MDA and insignificant increase in AST, ALT, ALP but urea and creatinine insignificantly decreased and improved in feed conversion rate.

Histopathological investigation revealed, Hepatic tissue, congestion and hyperplasia in bile duct epithelium. Renal tubules undergo interstitial aggregation of lymphocytes and regeneration. Intestine shows slight edema. spleen and bursa show hyperplasia of lymphocyte in white pulp.

It could be concluded that Moringa leaf extract act antibacterial, growth promoter, antioxidant and have benefits effect in immunity and hemato-biochemical parameters.
\end{abstract}

Keywords: Moringa Oleifera; Leaf Extract; Broiler Chicken; Histopathology.

\section{Introduction}

Chicken industry is one of the most dynamic of world agribusiness trade. Hence, research on meat production globally indicates poultry as fastest growing livestock sector especially in developing countries over several years; antibiotics are widely used in chicken for therapeutic use to treat diseases, prophylactic use to prevent infections or as growth promoters. However, problems associated with the use of antibiotics in poultry production include drug toxicity and residual effect [1]. Extensive use of antibiotics renders most antimicrobial agents inefficient in controlling some bacterial diseases [2].

Moringa oleifera plant possesses medicinal properties [3]. Moringa oleifera leaf extract has antibacterial properties [4]. Moringa oleifera was claimed to boost immune systems [5]. Its exhibit antitumor, anti-inflammatory and antiulcer activities [6]. Moringa oleifera are rich sources for natural anti-oxidants as tocopherols, flavonoids and vitamin $\mathrm{C}$ and essential oils [7] Moringa oleifera have several advantages over commonly used commercial antibiotics, since they are residue free and are generally recognized as safe and commonly used in the food industry [8]. The aim of the present study is to investigate the antibacterial ability of Moringa oleifera leaf extract against some pathogenic bacteria, its effect in body performance, some hematobiochemical parameters, some antioxidant enzymes as well as pathological changes in some internal organ in broiler chickens

\section{Material and methods}

\subsection{Bacteriological examination}

Cloacal swabs were collected from 300 chicks, one day old (50 dead, 50 diseased and 200 healthy). All swabs were collected aseptically, inoculated into nutrient broth aerobically at $37^{\circ} \mathrm{C}$ overnight, subculturing on nutrient agar and MacConkey agar plates, incubated for $24 \mathrm{~h}$ at $37^{\circ} \mathrm{C}$, colonies were identified [9].

\subsection{Serological identification}

The isolated E. coli and Salmonella species strains were serotyped using slide agglutination test against polyvalent and monovalent standard serum obtained from Denka sickon company LTD Tokyo Japan, using methods of [10].

Collection and Preparation of Aqueous and Ethanolic Extract Leaf of moringa oleifera was collected; air dried and pounded using mortar and pestle prior to extraction (watery and ethyl alcohol) [11]. 


\subsection{Antibiotic sensitivity test (in vitro)}

Susceptibility of isolated Salmonella spp and E. coli to moringa oleifera leaf extract in comparison to some chemotherapeutic agents was tested by disc diffusion method [12].

\subsection{Birds and experimental design}

Post bacteriological examination for 200 healthy chickens nearly equal in the live body weight (38-40gm), 120 chicks free from any bacterial infection were divided into 3 group ( 40 chicks each), $1^{\text {st }}$ group served as control group. $2^{\text {nd }}$ and $3^{\text {rd }}$ groups supplemented with $200 \mathrm{mg} / \mathrm{kgm}$ bwt wattery and alcoholic extract of moringa oleifera leaf in drinking water respectively for 30 days (from $1^{\text {st }}$ day of age up $30^{\text {th }}$ day of age)

\subsection{Body weight}

From each group 5 chicks were weighted individually at the start of the experiment and at $1^{\text {st }}$ day post supplementation (corresponding $31^{\text {th }}$ day of age) and consumed diets were recorded for calculation of weight gain and feed conversion rate.

\subsection{Blood samples}

At $1^{\text {st }}$ and $10^{\text {th }}$ day post supplementation 5 chicks from each group were sacrificed and two blood samples were collected. First sample was taken in tube contain EDTA as anticoagulant for hematological studies according [13], superoxide dismutase (SOD) determined spectrophotometrically [14]. Malonodialdehyde (MDA) $[15], 2^{\text {nd }}$ sample was used for obtain clear serum for estimation total protein [16], albumin [17], globulin was calculated as difference between total protein and albumin, (AST \& ALT) [18], ALP [19], uric acid [20] creatinine [21].

\subsection{Pathological examination}

Specimens were taken from liver, kidneys, intestine, spleen and bursa of the sacrificed chicks and directly fixed in $10 \%$ neutral buffered formalin. Five micron thick paraffin sections were prepared, stained with hematoxylin and eosin and examined microscopically [22] Statistical analysis the obtained data was analysed (T test) [23].

\section{Results}

Bacteriological and hematobiochemical results were recorded in tables (1-8)

Moringa oleifera leaf extract addition : Liver show hyperplasia in bile duct epithelium of watery extract (Fig 1), alcoholic extract shows liver congestion (Fig 2), kidney of watery extract shows interstitial aggregation of lymphocytes (Fig, 3) an alcoholic extract shows regenerative attempts in the renal tubules (Fig 4), Intestine of alcoholic extract shows slight edema (Fig 5) Bursa of watery extract shows hyperplasia in constituent cells (Fig, 6) and alcoholic extract shows severe hyperplasia in bursal lymphocytes (Fig,7), Spleen of watery moringa extracts showing thickening of splenic arterioles (arrow) and depletion of white pulp (arrowhead) (Fig 8),Spleen of alcoholic-moringa extract shows hyperplasia in the lymphocytes of white pulp Fig (9).

Table 1: Prevalence of Bacterial Isolates from Cloacae Swabs.

\begin{tabular}{|c|c|c|c|c|c|c|c|c|c|}
\hline \multirow{2}{*}{ Swabs } & \multirow{2}{*}{$\begin{array}{l}\text { No. of } \\
\text { swabes }\end{array}$} & \multicolumn{2}{|c|}{ Single isolates } & \multicolumn{2}{|c|}{ Mixed isolates } & \multicolumn{2}{|c|}{ Total +ve } & \multicolumn{2}{|c|}{ Total -ve } \\
\hline & & No & $\%$ & No & $\%$ & No & $\%$ & No & $\%$ \\
\hline dead & 50 & 12 & 24 & 14 & 28 & 26 & 52 & 24 & 48 \\
\hline diseased & 50 & 15 & 30 & 13 & 26 & 28 & 56 & 22 & 44 \\
\hline healthy & 200 & 11 & 5.5 & 17 & 8.5 & 28 & 14 & 172 & 86 \\
\hline
\end{tabular}

Table 2: Incidence of Different Bacterial Pathogens Isolated from Examined Cloacal Swabs

\begin{tabular}{|c|c|c|c|c|c|c|c|}
\hline \multirow{2}{*}{ Swabs orgin } & \multirow{2}{*}{ Swabs number } & \multicolumn{6}{|c|}{ Isolates } \\
\hline & & Type & No & $\%$ & Isolated organisms & No & $\%$ \\
\hline \multirow{7}{*}{ Dead chicks } & \multirow{7}{*}{50} & \multirow{4}{*}{ Single } & \multirow{4}{*}{12} & \multirow{4}{*}{24} & E.coli & 5 & 41.66 \\
\hline & & & & & Proteus & 3 & 25 \\
\hline & & & & & Salmonella spp. & 2 & 16.66 \\
\hline & & & & & Staph. Aureus & 2 & 16.66 \\
\hline & & \multirow{3}{*}{ Mixed } & \multirow{3}{*}{14} & \multirow{3}{*}{28} & Pseudomonas+ E.coli+ Proteus & 5 & 35.71 \\
\hline & & & & & Staph. Aureus+ klebsiella & 8 & 57.14 \\
\hline & & & & & E.coli+ Salmonella spp. & 1 & 7.14 \\
\hline \multirow{7}{*}{ Diseased chicks } & \multirow{7}{*}{50} & \multirow{4}{*}{ Single } & \multirow{4}{*}{15} & \multirow{4}{*}{30} & E.coli & 6 & 40 \\
\hline & & & & & Salmonella spp. & 1 & 6.67 \\
\hline & & & & & Strept. spp. & 4 & 26.67 \\
\hline & & & & & Proteus & 4 & 26.67 \\
\hline & & \multirow{3}{*}{ Mixed } & \multirow{3}{*}{13} & \multirow{3}{*}{26} & Proteus + klebsiella & 5 & 38.46 \\
\hline & & & & & Staph. Aureus+ E.coli & 3 & 23.08 \\
\hline & & & & & Staph. Aureus+ Proteus & 5 & 38.46 \\
\hline \multirow{8}{*}{ Healthy chicks } & \multirow{8}{*}{200} & \multirow{4}{*}{ Single } & \multirow{4}{*}{11} & \multirow{4}{*}{5.5} & E.coli & 4 & 36.36 \\
\hline & & & & & Salmonella spp. & 2 & 18.18 \\
\hline & & & & & Pseudomonas & 3 & 27.27 \\
\hline & & & & & Strept. spp. & 2 & 18.18 \\
\hline & & \multirow{4}{*}{ Mixed } & \multirow{4}{*}{17} & \multirow{4}{*}{8.5} & E coli + Staph. Aureus & 6 & 35.29 \\
\hline & & & & & Proteus + Staph. Aureus+ E coli & 5 & 29.41 \\
\hline & & & & & Salmonella spp.+ Proteus & 4 & 23.52 \\
\hline & & & & & Salmonella spp + E.coli & 2 & 11.76 \\
\hline
\end{tabular}

Table 3: Serological Identification of Tsolated E.Coli and Salmonella Strains

\begin{tabular}{llllll}
\hline Isolated bacteria & serotyp & Dead (5) & Diseased (6) & Healthy (4) & Total \\
\hline \multirow{3}{*}{ E.coli } & O157 & 1 & 2 & 1 & 4 \\
& O78 & 2 & 1 & 2 & 5 \\
\multirow{3}{*}{ Salmonella } & O11 & 1 & 3 & 1 & 6 \\
& & Dead (2) & Diseased (1) & Healthy (2) & 2 \\
\hline
\end{tabular}


Table 4: In-Vitro Antibacteral Effect of Moringa Olefera on Some Isolated Bacteria

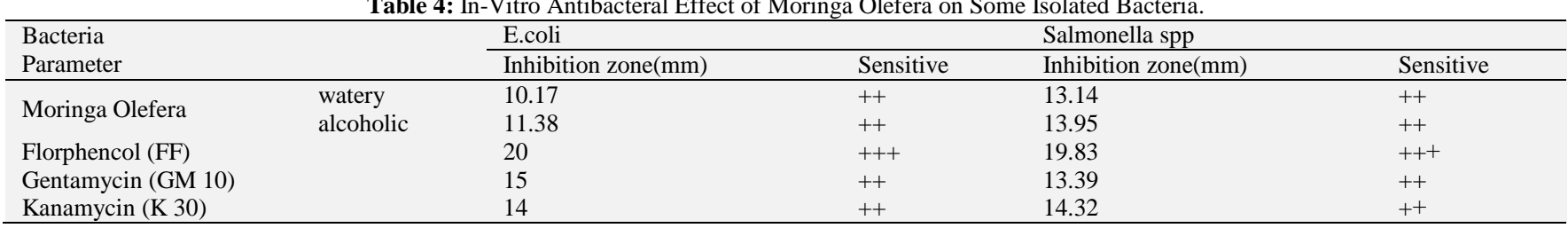

Table 5: Effect of Moringa Olefera in Body Weight of Broiler $(\mathrm{N}=5)$.

\begin{tabular}{|c|c|c|c|c|c|c|}
\hline \multirow{2}{*}{ Period\&groips Parameter } & \multicolumn{3}{|l|}{$1^{\text {st }}$ day } & \multicolumn{3}{|l|}{$10^{\text {th }}$ day } \\
\hline & control & Watery & alcoholic & control & Watery & alcoholic \\
\hline Initial body & 39.83 & 40.01 & 38.97 & 39.88 & 39.07 & 40.05 \\
\hline weight & \pm 0.27 & \pm 0.38 & \pm 0.22 & \pm 0.24 & \pm 0.25 & \pm 0.24 \\
\hline weight & \pm 5.34 & \pm 7.84 & \pm 6.38 & \pm 5.83 & \pm 6.95 & \pm 8.43 \\
\hline Weight & 1380.92 & 1490.25 & 1518.43 & 1934.81 & 1966.35 & 1975.50 \\
\hline gain & \pm 6.42 & \pm 4.81 & \pm 5.48 & \pm 6.53 & \pm 5.49 & \pm 8.43 \\
\hline Feed & 1640.42 & 1696.06 & 1503.18 & 2603.07 & 2615.53 & 2010.04 \\
\hline consumption & \pm 2.97 & \pm 3.44 & \pm 3.81 & \pm 2.57 & \pm 4.83 & \pm 3.72 \\
\hline FCR & 1.19 & 1.12 & 0.99 & 1.35 & 1.33 & 1.02 \\
\hline
\end{tabular}

$\mathrm{FCR}=$ Feed Conversion rate $*$ Significant at $\mathrm{P}<0.05 * *$ Significant at $\mathrm{P}<0.001$

Table 6: Effect of Moringa Olefera in Blood Picture, Phagocytosis \& Killing \% in Broiler (N=5).

\begin{tabular}{|c|c|c|c|c|c|c|}
\hline \multirow{2}{*}{$\begin{array}{l}\text { Period\&groips } \\
\text { Parameter }\end{array}$} & \multicolumn{3}{|l|}{ 1st day } & \multicolumn{3}{|l|}{$10^{\text {th }}$ day } \\
\hline & control & watery & alcoholic & control & Watery & alcoholic \\
\hline \multirow{2}{*}{$\mathrm{RBCs}\left(10^{6} / \mathrm{mm}^{3}\right)$} & $3.35 \pm$ & $3.95 \pm$ & $4.04 \pm$ & $3.41 \pm$ & $3.58 \pm$ & $3.79 \pm$ \\
\hline & 0.17 & $0.14^{*}$ & $0.21 *$ & 0.21 & 0.19 & 0.26 \\
\hline $\begin{array}{l}\mathrm{HB} \\
(\mathrm{gm} / \mathrm{dl})\end{array}$ & 0.20 & $0.34^{*}$ & $0.52 *$ & 0.32 & 0.29 & 0.40 \\
\hline \multirow{2}{*}{$\mathrm{PCV} \%$} & $34.28 \pm$ & $37.22 \pm$ & $37.85 \pm$ & $34.60 \pm$ & $35.17 \pm$ & $34.69 \pm$ \\
\hline & 0.86 & $0.94 *$ & $0.89^{*}$ & 0.94 & 0.78 & 0.98 \\
\hline \multirow{2}{*}{$\begin{array}{l}\text { WBCs } \\
\text { (U/L) }\end{array}$} & $11.31 \pm$ & $13.13 \pm$ & $13.34 \pm$ & $11.52 \pm$ & $12.49 \pm$ & $12.08 \pm$ \\
\hline & 0.74 & $0.16^{*}$ & $0.22 *$ & 0.89 & 0.31 & 0.52 \\
\hline \multirow{2}{*}{ Phagocytosis } & $54.09 \pm$ & $58.16 \pm$ & $58.62 \pm$ & $54.16 \pm$ & $57.03 \pm$ & $58.06 \pm$ \\
\hline & 1.21 & $1.37^{*}$ & $1.42^{*}$ & 1.27 & 1.23 & 1.55 \\
\hline Killing & $43.19 \pm$ & $44.84 \pm$ & $45.04 \pm$ & $43.31 \pm$ & $44.15 \pm$ & $44.21 \pm$ \\
\hline$\%$ & 1.22 & 1.05 & 1.13 & 1.26 & 1.32 & 1.40 \\
\hline
\end{tabular}

* Significant at $\mathrm{P}<0.05$

Table 7: Effect of Moringa Olefera on Some Biochemical Parameters in Broiler (Mean \pm S.E.)

\begin{tabular}{|c|c|c|c|c|c|c|c|}
\hline \multirow{2}{*}{$\begin{array}{l}\text { Period\& groips } \\
\text { Parameter }\end{array}$} & & \multicolumn{3}{|l|}{$1^{\text {st }}$ day } & \multicolumn{3}{|c|}{$10^{\text {th }}$ day } \\
\hline & & control & watery & alcoholic & Control & watery & alcoholic \\
\hline \multirow{8}{*}{$\begin{array}{l}\text { Protein picture } \\
(\mathrm{mg} / \mathrm{dl})\end{array}$} & \multirow{2}{*}{ T.Protein } & $5.12 \pm$ & $6.44 \pm$ & $6.63 \pm$ & $5.19 \pm$ & $5.68 \pm$ & $5.92 \pm$ \\
\hline & & 0.32 & $0.38 *$ & $0.43 *$ & 0.28 & 0.41 & 0.39 \\
\hline & \multirow{2}{*}{ Albumin } & $2.99 \pm$ & $3.65 \pm$ & $3.77 \pm$ & $2.90 \pm$ & $3.21 \pm$ & $3.20 \pm$ \\
\hline & & 0.20 & $0.19 *$ & $0.20 *$ & 0.24 & 0.22 & 0.35 \\
\hline & \multirow{2}{*}{ Globulin } & $2.13 \pm$ & $2.79 \pm$ & $2.86 \pm$ & $2.29 \pm$ & $2.47 \pm$ & $2.72 \pm$ \\
\hline & & 0.21 & $0.17 *$ & $0.14^{*}$ & 0.23 & 0.19 & 0.21 \\
\hline & \multirow{2}{*}{$\mathrm{A} / \mathrm{G}$} & $1.40 \pm$ & $1.31 \pm$ & $1.32 \pm$ & $1.27 \pm$ & $1.30 \pm$ & $1.32 \pm$ \\
\hline & & 0.18 & 0.13 & 0.21 & 0.18 & 0.17 & 0.15 \\
\hline \multirow{6}{*}{$\begin{array}{l}\text { Liver } \\
\text { Enzymes } \\
\text { U/L( }\end{array}$} & \multirow{2}{*}{ AST } & $49.38 \pm$ & $49.67 \pm$ & $49.70 \pm$ & $49.50 \pm$ & $49.62 \pm$ & $59.72 \pm$ \\
\hline & & 1.05 & 1.48 & 1.93 & 1.24 & 1.61 & 1.50 \\
\hline & \multirow{2}{*}{ ALT } & $63.71 \pm$ & $64.03 \pm$ & $64.08 \pm$ & $63.47 \pm$ & $63.53 \pm$ & $63.49 \pm$ \\
\hline & & 1.48 & 1.61 & 1.52 & 1.59 & 1.36 & 1.68 \\
\hline & \multirow{2}{*}{ ALP } & $43.21 \pm$ & $43.45 \pm$ & $43.52 \pm$ & $43.18 \pm$ & $43.24 \pm$ & $43.28 \pm$ \\
\hline & & 1.85 & 1.25 & 1.69 & 1.93 & 1.21 & 1.88 \\
\hline \multirow{4}{*}{$\begin{array}{l}\text { Kidney } \\
\text { Function } \\
\text { )mg/dl( }\end{array}$} & \multirow{2}{*}{ Uric acid } & $5.36 \pm$ & $5.19 \pm$ & $5.27 \pm$ & $5.30 \pm$ & $4.21 \pm$ & $4.24 \pm$ \\
\hline & & 0.41 & 0.43 & 0.31 & 0.30 & 0.26 & 0.52 \\
\hline & \multirow{2}{*}{ Creatinine } & $1.15 \pm$ & $1.12 \pm$ & $1.10 \pm$ & $1.17 \pm$ & $1.14 \pm$ & $1.13 \pm$ \\
\hline & & 0.10 & 0.13 & 0.18 & 0.15 & 0.27 & 0.12 \\
\hline
\end{tabular}

* Significant at $\mathrm{P}<0.05$

Table 8: Effect of Moringa Olefera on Some Antioxidant Enzymes in Broiler (Mean \pm S.E.)

\begin{tabular}{|c|c|c|c|c|c|c|}
\hline \multirow{2}{*}{$\begin{array}{l}\text { Period\& groips } \\
\text { Parameter }\end{array}$} & \multicolumn{3}{|l|}{ 1st day } & \multicolumn{3}{|l|}{ 10th day } \\
\hline & control & Watery & alcoholic & Control & watery & alcoholic \\
\hline SOD & $236.14 \pm$ & $244.09 \pm$ & $245.13 \pm$ & $238.95 \pm$ & $242.16 \pm$ & $243.25 \pm$ \\
\hline (U/ml) & 2.59 & $1.85^{*}$ & $1.95^{*}$ & 2.61 & 1.69 & 1.95 \\
\hline MDA & $14.38 \pm$ & $11.15 \pm$ & $10.89 \pm$ & $14.64 \pm$ & $13.32 \pm$ & $13.06 \pm$ \\
\hline$(\mathrm{nmol} / \mathrm{ml})$ & 0.89 & $0.97 *$ & $0.88^{*}$ & 0.68 & 0.88 & 0.96 \\
\hline
\end{tabular}

* Significant at $\mathrm{P}<0.05$ 


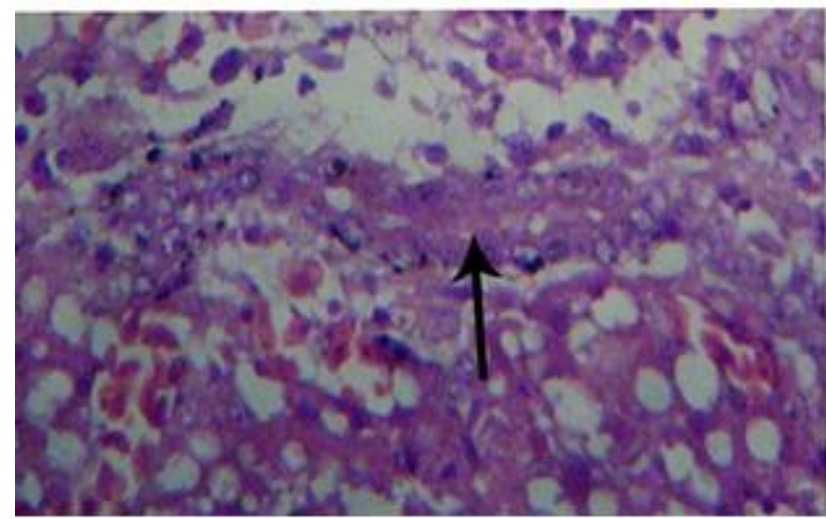

Fig 1: Liver of Broiler Chicken in Watery -Moringa Leaf Extract Showing Hyperplasia in Bile Duct Epithelium (HE X 400)

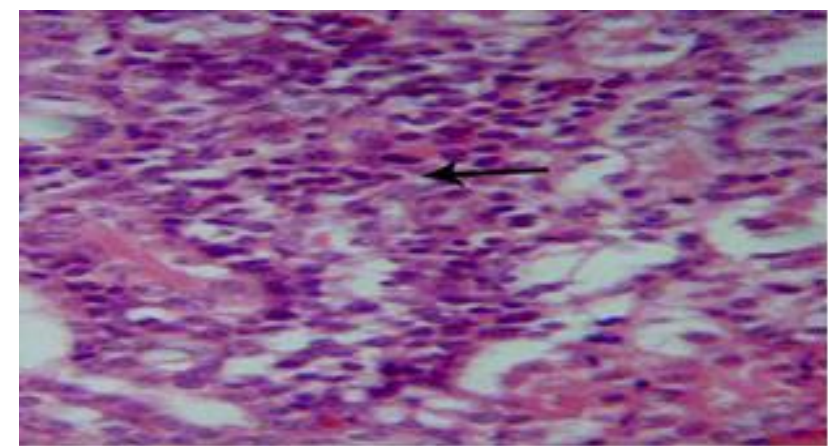

Fig 3: Kidney of Broiler Chicken in Watery -Moringa Extract Showing Interstitial Aggregation of Lymphocytes. (He X 400)

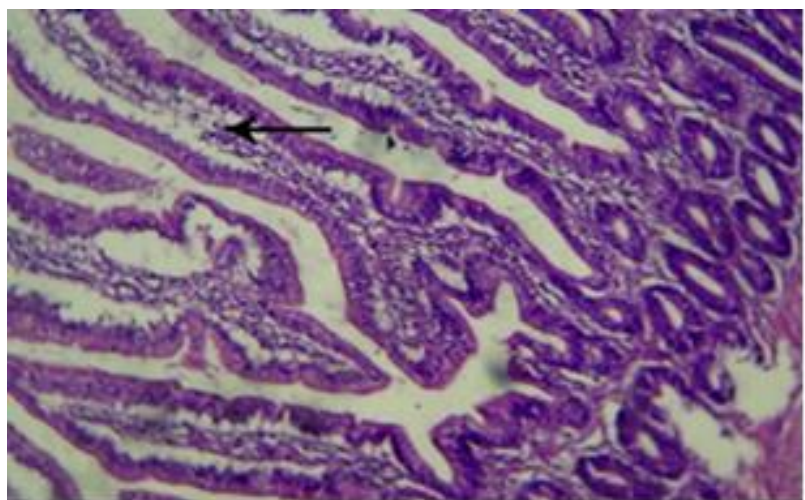

Fig 5: Intestine of Broiler Chicken in Alcoholic-Moringa Extract Showing Slight Edema. (HE X 200).

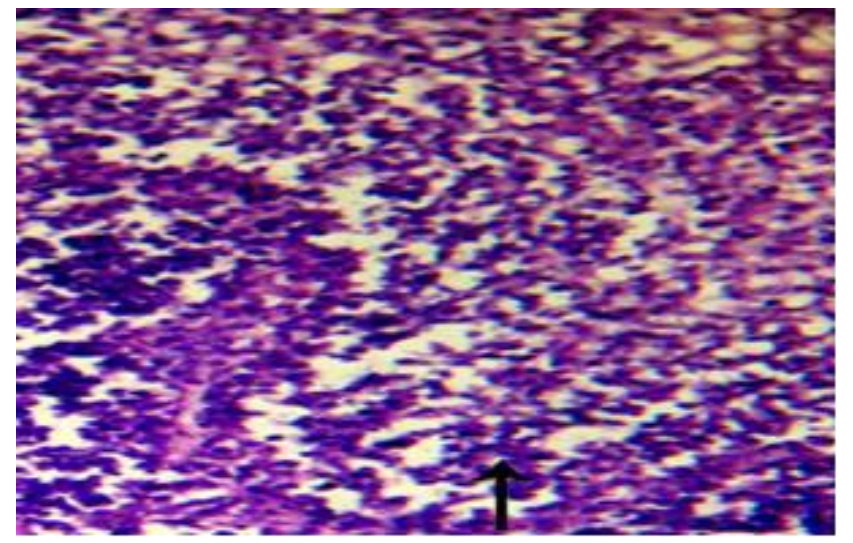

Fig 7: Bursa of Broiler Chicken in Alcoholic-Moringa Extract Showing Severe Hyperplasia in the Bursal Lymphocytes. (HE X 400).

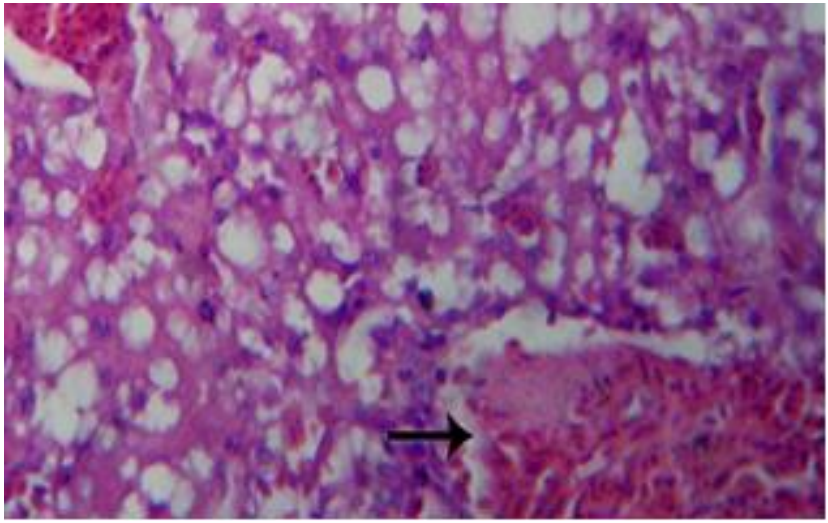

Fig 2: Liver of Broiler Chicken in Alcoholic-Moringa Extract Showing Congestion $(\mathrm{Hex} 400)$

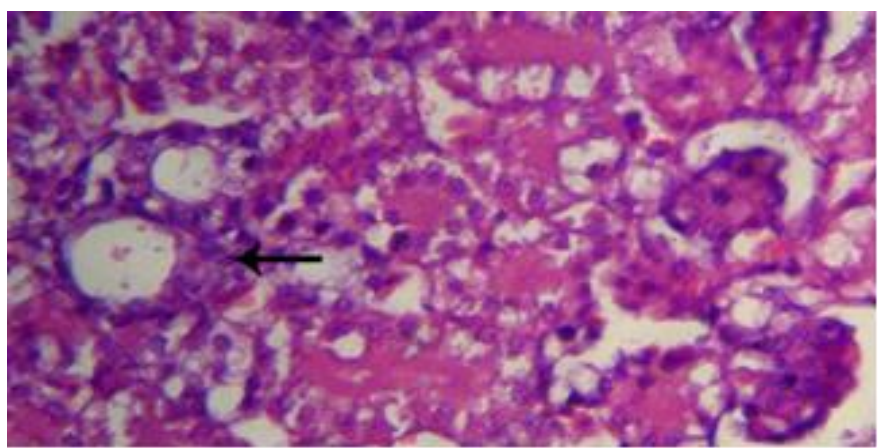

Fig 4: Kidney of Broiler Chicken in Alcoholic-Moringa Extracts Showing Regenerative Attempts in the Renal Tubules (He X 400)

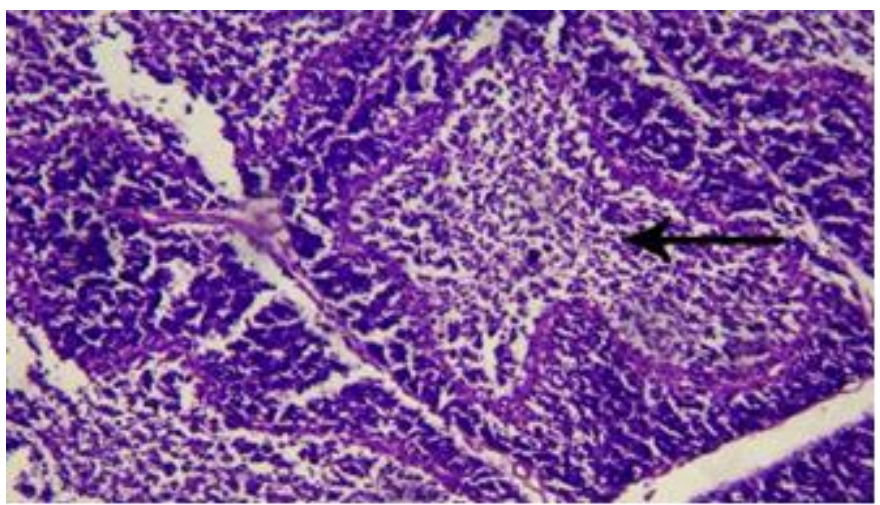

Fig 6: Bursa of Broiler Chicken in Watery Moringa Olefera Extract Showing Hyperplasia in the Constituent Cells.(He X 200(

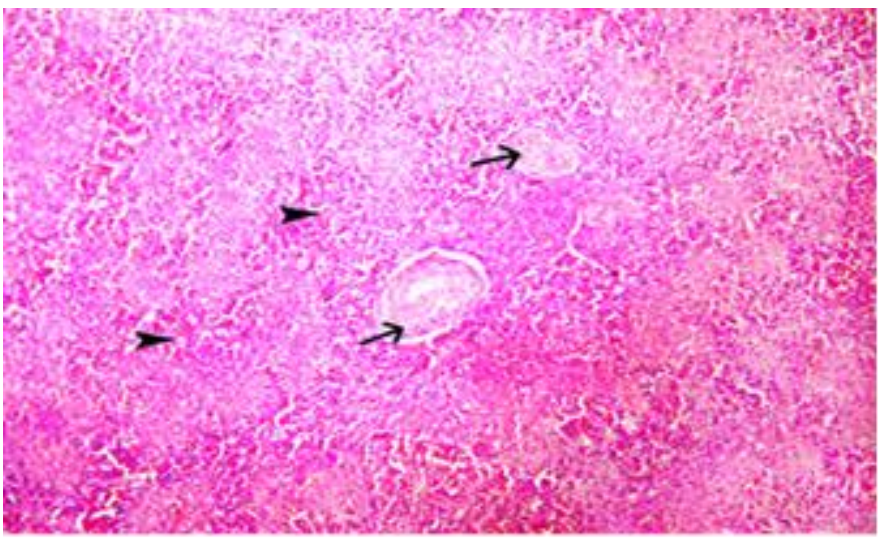

Fig 8: Spleen of Broiler Chicken in Watery Moringa Olefera Extracts Showing Thickening of Splenic Arterioles (Arrow) and Depletion of White Pulp (Arrowhead), H E X300. 


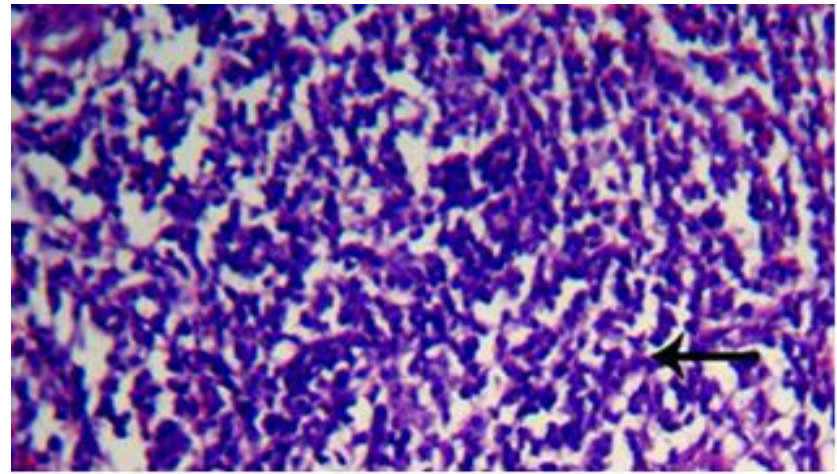

Fig 9: Spleen of Alcoholic-Moringa Extract Shows Hyperplasia in the Lymphocytes of White Pulp. (HE X 400).

\section{Discussion}

Out of 300 examined swabs $26(52 \%)$ dead, $28(56 \%)$ diseased and $28(14 \%)$ from healthy chicks were positive for bacteria either single or mixed isolants (table 2). Our data are in accordance with [24] who isolates E. coli, salmonella spp., Pseudomonas, Proteus and these bacteria may be found in single or mixed infections. Salmonella spp. Were isolated from diseased broiler chickens [25]. Our results agreed with results recorded by [26] isolate Salmonella species and E coli from initial few weeks of chicks life.

The isolated E. coli (15) were differentiated into 3 typed isolates \{O11 (6), O78 (5) and O157 (4)\} serotypes (table 3). similar results recorded [27]. Serological identification of Salmonella isolates revealed that Salmonella entritidis (2) and Salmonella typhimurium (3) was the most serotype in our study. same results were obtained by [28] isolate Salmonella entritidis, Salmonella Gallinarum and Salmonella typhimurium were the commonly isolated serotypes from broiler flocks.

In the present study, Moringa oleifera leaf extracts inhibits growth of Salmonella species and E. coli. alcoholic leaf extract induced zone of inhibition more than watery extract (table, 4). This finding was supported by [4] stated that E. coli sensitive to Moringa oleifera leaf extract. Ethanoic leaf extract of Moringa oleifera induced zone of inhibition against Salmonella typhii more than inhabitation zone of E. coli [29]. Moringa oleifera extract have antibacterial properties [30]. Moringa oleifera leaf extract used as alternatives to antibiotics [7]. Medicinal plants as Moringa oleifera may represent an alternative treatment for non severe cases of infectious diseases [31].

Healthy broiler chicks received Moringa leaf extract (watery and alcoholic) resulted a significant increase in body weight, weight gain and improved in feed conversion rate (table, 5). These obtained results go in agreement with [32], [33] and [34] in broiler chickens supplemented with moringa extract. varying concentrations of moringa aqueous leaf extract induce increase in body weight gain and improved in feed conversion rate in Cobb broilers [35]. Elevation in weight gain and improved in feed conversion rate may be attributed to presence of high amounts of vitamins, minerals and amino acids in Moringa leaf [36].

In the current work, broiler chickens supplemented with 200 $\mathrm{mg} / \mathrm{kgm}$ bwt Moringa leaf extract (watery and alcoholic) induce significant increase in total erythrocytic count, haemoglobin content, packed cell volume, total leukocytic count, phagocytosis and killing\% at $1^{\text {st }}$ day post administration (table, 6). Same result was reported by [37] in broiler chickens received Moringa leaf extract. Elevation in erythrocytic count, haemoglobin content and packed cell volume \% post using Moringa may be due to presence of saponin in Moringa [38] and/or alkaloids and flavonoids in Moringa induce increase in total erythrocytic count, haemoglobin content and packed cell volume \% [39]. Moringa in dose of 100-400 mg $/ \mathrm{kg}$ induced increase in leukocytic counts [40]. Moringa oleifera induce improvement in phagocytosis and killing \% [41 and 42] in broilers chickens and rats respectively.

The obtained results revealed significant increase in serum total proteins, albumin and globulins at $1^{\text {st }}$ day post supplementation of $200 \mathrm{mg} / \mathrm{kgm}$ bwt. Moringa leaf extract in drinking water to broil- er chickens (table, 7). Our results were coinciding with those obtained by [39] who stated that moringa induce significant increase in total protein and albumin. Same result was recorded by [1-34] in broiler chickens received moringa. Elevations in total protein our study may be due to moringa are rich in both essential and sulfur-containing amino acids [43] and/ or due to Moringa oleifera contain large amount of protein [44].

In the present experiment, Moringa leaf extract in a dose of 200 $\mathrm{mg} / \mathrm{kgm}$ bwt induces insignificant increase in AST, ALT and ALP beside insignificant decrease in urea and creatinine (table, 7). Same changes were observed [5] in broilers fed Moringa leafs. Moringa leaf extract induce insignificant effect in liver enzymes, urea and creatinine [45]. Also, [41] reported Moringa extract induce non significant decreases in uric acids of broilers. This obtained result was similar to those recorded [46] who found that Moringa leaf extract induce non significant effect in liver enzymes. Moringa leaf extract have hepatoprotective effect [47].

In this study, the superoxide dismutase showed significant increased beside significant decrease in malonodialdehyde in broiler chickens received Moringa leaf extract (table, 8). Same changes were recorded [48] in laying hens received Moringa leaf extract. Moringa contain antioxidant enzymes, reducing intensity of lipid peroxidation and inhibiting generation of free radicals [49-50]. The antioxidant effect of Moringa leaf extract may be due to presence of polyphenols, anthocyanin, thiocarbamates and glycosides which remove free radicals, activate antioxidant enzymes and inhibit oxidases [51] and/ or due to Moringa suppress formation of reactive oxygen species and free radicals [52]

The histomorphological changes in Liver was hyperplasia in bile duct epithelium and congestion post using moringa extract. Same microscopical lesions were recorded by [53]. kidney showed interstitial aggregation of lymphocytes and regenerative attempts in the renal tubules. These findings were supported by [46]. Intestine showed slight edema as recorded by [45]. In the immune organs (bursa and spleen) showed hyperplasia of lymphocytes. The microscopic lesions recorded in the present investigation were almost similar to the lesions recorded by [37].

It could be concluded that Moringa oleifera leaf extract act as antibacterial, growth promoters, antioxidant and exhibits some benefits effect on immunity and hemato-biochemical parameters.

\section{References}

[1] Ogbe A, John P and Affiku, P. (2012). Effect of aqueous extracts (Moringa oleifera and gum arabic) in comparison with antibiotic on growth performance, haematological and some biochemical parameters of broiler. Res. J. of Recent Sci.1 (7)10-18.

[2] Lar, P.; Ojile, E.; Dashe, E. and Oluoma J. (2011) Antibacterial activity of moringa oleifera seed extracts on some Gr-ve bacteria. African J. of Natur Sci., 14, 57-62.

[3] Fahey J. (2005) Moringa oleifera: a review of the medical evidence for its nutritional, therapeutic, and prophylactic properties. Part 1. Trees Life J.; 1: 1-5.

[4] Thilza I, Sanni S, zakari A, Muhammed T and Musa, B. (2010). In vitro antimicrobial activity of water extract of Moringa oleifera leaf stalk on bacteria normally implicated in eye disease. Academia Arena, 2: 80-83. 
[5] Olugbemi, T; Mutayoba, S. and Lekule, F. (2010) Effect of Moringa oleifera in Cassava based diets to broiler. In Inter. J. of Poultry Sci., 9, 4, 63-67.

[6] Chumark, P.; Khunawat, P.; Sanvarinda, Y.; Morales, P. and Pongrapeeporn, K. (2008) the in vitro and in vivo antioxidant properties and hypolipidaemic activities of the water extract of Moringa oleifera leaf. J. of Ethnopharmacology, 116, 439-446. http://dx.doi.org/10.1016/j.jep.2007.12.010.

[7] Lewis, M., Rose, S., Mackenzie, A. and Tucker, L. (2003) Effects of Moringa oleifera leaf extracts on growth performance of broiler. Br. Poult. Sci. 44:43-44. http://dx.doi.org/10.1080/713655281.

[8] Varel, V. (2002) Carvacrol and thymol reduce swine waste odor and pathogens: stability of oils. Curr. Microbiol; 44(1): 38-43. http://dx.doi.org/10.1007/s00284-001-0071-z.

[9] Cruickshank W, Duguid J, Marmion B and Swain R (1975): Medical Microbiolgy 12t" Ed. W. and S.living limited Edingurg and London67-77.

[10] Boop, C.; Brenner, F.; Wells, J and Strockbine, N (1999): Escherichia Shigella \& Salmonella. Manual of Clinical Microbiology. 7thed. Washington: ASM Press 59-74.

[11] Njar V, Alao T, Okogun J and Hol, H (1993) Methoxy cathin-6one: A new alkaloid from the stem wood of Quassia amara. Planta Med, 59: 259-261. http://dx.doi.org/10.1055/s-2006-959664.

[12] Quinn P. Carte M., Markeryo B and Carter G (1994): Clinical Vet. Microbiology Year book-wolf publishing-Europe Limited.

[13] Jain, N. (2000): Schalm's vet Hematology 4th Ed p 55-96 Lee and Philadelphia.

[14] Paoletti, F. and Mocali, A. (1990). Determination of superoxide dismutase activity by purely chemical system based on NAD (P) H oxidation. Methods in Enzymology, 186, 209-219. http://dx.doi.org/10.1016/0076-6879(90)86110-H.

[15] Esterbauer, H. (1982). Lipid peroxidation and cancer. In Free Radicals. Pp. 101-128. London: Academic Press.

[16] Doumas, B.; Cartor, R.; Peers, T. and Schafer, R. (1981): A candidate reference method for determination total protein in serum Clin Chem, 27, and 1642.

[17] Drupt, F (1974) Colorimetric methed for determination of albumin Phar. Bio.9.

[18] Reitman S and Frankle S (1957): A colormetric determimation of GOT and GPT activity. Am. J. Clinic. Path. 28: 56.

[19] John, D. (1982) Determination of Alkaline Phosphates. 9th Ed. 580-581.

[20] Coalombe J and Faurean, 1. (1963) A simple method for colorimetric determ-ination of urea. Clin. Chem., 9:102-108.

[21] Husdan H and Roporpot A (1968) Estimaton of creatinin Clin.Chem14, 22

[22] Suvarna, S.; Layton, C. and Bancroft, J. (2013): Bancroft's Theory and Practice of Histological Techniques. 7th ed., Churchill Livingstone. Elsevier, England.

[23] Petrie A and Watson A (1999): Statistical for Vet. and Animal Sci. Ltd U.

[24] Ali, M. (1993) Studies on isolation and antibiotic sensitivity of bacteria causally associated with omphalitis in chickens. M.V.Sc (Hons.) Thesis, Dept. Vet. Microbiol. Univ. Agri. Faisalabad.

[25] Shivaprasad, H. (2000) Fowl typhoid and pullorum disease. Review Sci. Technology, 19(2): 405-424.

[26] Venkanagouda, G. Krishnappa, R. and Upodhye, S. (1996) Bacterial etiology of early chick mortality. Indian Vet. J, v73 (3) 253-256.

[27] Abd El-Hamed, G. (2014) Molecular detection of antibiotic resistant genes of avian pathogenic E. coli. Thesis (Ph.D)-Cairo Univ. Fac. of Vet Med. Microbiology Depart.

[28] Ahmed, M. (2014) Immunology and Mycology Studies on recent methods for detection of Salmonellae species isolated from poultry. Thesis (M.Sc.) Banha Univ. fac. of Vet. Med.. Department of Bacteriology.

[29] Vinoth. B, Manivasagaperumal, R. and Balamurugan, S. (2012) phytochemical analysis and antibacterial activity of Moringa oleifera lam, India. Inter. j. 2(3):98-102

[30] Patel, J. (2011). Antibacterial activity of some medicinal plants used in India folklore. In Inter. J. of Phytomedicine, 3, p. 261-269.

[31] Ajibesin, K.; Ekpo, B., Essien, E. and Adesanya, S. (2008) Ethanobotanical Survey of Akwa lbom State of Nigeria. J. of Ethanopharmacology, 115(3)87-98. http://dx.doi.org/10.1016/j.jep.2007.10.021

[32] Banjo, O. (2012) Growth and Performance as affected by Moringa oleifera leaf meal in Broiler chicks diet. J. of Biology, Agric. and Health 2 (9) 34-42.

[33] Teteh, A. Lawson, E.; Tona1, K.; Decuypere, .E. and Gbeassor, M. (2013) Moringa Oleifera Leave: Hydroalcoholic Extract and Effects on Growth Performance of Broilers. International J. of Poultry Science 12 (7): 401-405, http://dx.doi.org/10.3923/ijps.2013.401.405.
[34] Makanjuola, B; Olorungbohunmi, T.; Oladele, B. and Boladuro B. (2014) Effect of Moringa oleifera leaf as a substitute for antibiotics on performance and blood parameters of broiler. Livestock Res. for Rural Develop. 26(8) 36-41.

[35] Portugaliza H. and Fernandez, J. (2012) Growth performance of Cobb broilers given varying concentrations of malunggay (Moringa oleifera lam.) aqueous leaf extract. Online J. Anim. Feed Res., 2 (6): 465-469.

[36] Nkukwana, T.; Muchenje, V., Pieterse, E., Masika, P.; Mabusela, T.; Hoffman, L. and Dzama, K. (2014) Effect of Moringa oleifera leaf on growth performance and carcass yield in broiler chickens. $\begin{array}{lll}\text { Livestock } & \text { sci. } & 161,\end{array}$ http://dx.doi.org/10.1016/j.livsci.2014.01.001

[37] Majambu, M. (2012) Therapeutic potential of Moringa oleifera leaf in broiler chickens: A review. Frontiers Pharmacol., 3(24): 1-12.

[38] Khalil, A. and Eladawy, T. (1994) Isolation, identification and toxicity of saponins from different legumes. Food Chemistry, 50(2): 197-201. http://dx.doi.org/10.1016/0308-8146(94)90120-1.

[39] Anwar, F., Latif, S. Ashraf, M. and Gilani, A. (2007).Moringa oleifera: A food plant with multiple medicinal uses. Phytother. Res. 21: 17-25. http://dx.doi.org/10.1002/ptr.2023.

[40] Auwal, M.; Tijjani, A.; Sadiq, M.; Saka, S. Mairiga, I., Shuaibu, A. and Gulani, I. (2013) Antibacterial and haematological activity of Moringa oleifera aqueous seed extract in rats. Sokoto J. of Vet. Sci. 11(1): 28-37.

[41] Du P, Lin P, Yang R and Hsu J (2007) Effect of dietary Moringa oleifera on growth performance, blood characteristics and immune response in broilers. J. of Chinese Society of Animal Sci., 36(3): 135-146.

[42] Adedapo A.; Mogbojuri, O. and Emikpe. B. (2012) Safety evaluations of aqueous extract of leaves of Moringa oleifera in rats. J. of Med. Plants Research, 3(8):586-591.

[43] Moyo, B.; Masika, P. and Muchenje, V. (2011) Nutritional characterization of Moringa oleifera leaves. African J. Biotech., 10 (60) 12925-12933.

[44] Onu P and Otuma, M (2008) Utilisation of heat treated sheep chopping in the diets of broiler finisher chicks, Int. J of Poult Sc 7 (2): 169-173. http://dx.doi.org/10.3923/ijps.2008.169.173.

[45] Ezejindu D.; Udemzue O. and Akingboye A. (2014) Hepatoprotective effects of moringa oleifera leaf on kidneys of rats. Amer. J of Eng. Res. 3(2) 157-161.

[46] Buraimoh, A. Bako, G and Ibrahim, B. (2011) Hepatoprotective Effect of Ethanolic Leave Extract of Moringa oleifera on Histology of Paracetamol Induced Liver Damage in Rats. Intern. J. of Anima and Vet. Advan 3(1) 10-13.

[47] Wallace R, Oleszek W, Franz C, Hahn I and Teichmann K (2010) Dietary plant bioactives for poultry health and productivity. British Poultry Science 51, 461-487. http://dx.doi.org/10.1080/00071668.2010.506908.

[48] Mohamed, F. and Nagwan, E. (2015) gentamycin-induced nephrotoxicity in chickens: modulatory role of moringa oleifera. Assiut Vet Med J 44(161)14-22.

[49] Ogbunugafor H, Eneh F, Ozumba A, Okpuzor J, Igwilo I and Onyekwelu O (2011) Moringa oleifera seed oil. Pakistan J. of Nutri 10 (5):409-414. http://dx.doi.org/10.3923/pjn.2011.409.414

[50] Arabshahi, D.; Devi V. and Urooj, A. (2007) Evaluation of antioxidant activity of some plant extracts. Food Chemistry, 100: 1100 1105. http://dx.doi.org/10.1016/j.foodchem.2005.11.014.

[51] Luqman S, Srivastava S, Kumar R, Maurya A and Chanda D. (2012) Experimental assessment of Moringa oleifera leaf and fruit for its antistress, antioxidant and scavenging potential using in vitro and in vivo assays. Med. Pak J Bot; 44: 1349-1358.

[52] Ogbe, A and Affiku, R (2011) Proximate study, mineral and antinutrient composition of Moringa oleifera leaf harvested from Lafia Nigeria: potential benifets in poultry nutrition. J. of Micro, Biotechn. And Food Sci.:1 (3) 96-108.

[53] Gupta, A. and Misra, N. (2006) Hepatoprotective activity of ethanolic extract of chamomile capitula in paracetamol intoxicated rats. Am. J. Pharm. Toxicol., 1: 17-20. http://dx.doi.org/10.3844/ajptsp.2006.17.20. 